\title{
Source Rock Potential and Thermal Maturity of the Eocene Nanka Formation (Ameki Group) In Anambra Basin: An Appraisal of Ogbunike Reference Locality, South Eastern Nigeria
}

\author{
${ }^{1}$ Chiaghanam O. I., ${ }^{2}$ Chiadikobi, K. C., ${ }^{3}$ Ikegwuonwu, O. N., \\ ${ }^{4}$ Omoboriowo, A. O., ${ }^{5}$ Onyemesili, O. C., ${ }^{6}$ Yikarebogha, Y. \\ ${ }^{1,2,5}$ Department of Geology, Anambra State University, Uli \\ ${ }^{3}$ Department of Geology, University of Nigeria, Nsukka \\ ${ }^{4}$ Department of Earth Sciences, Federal University of Petroleum Resources, Effurun. \\ ${ }^{6}$ Department of Petroleum Resources, Benin City
}

\begin{abstract}
Source rock potential and thermal maturity of the Eocene Nanka Formation of Ogbunike,south eastern Nigeria was assessed in this research work.The rock-eval pyrolysis result recorded a value range of 0.04 to $0.11,0.44$ to 1.32 and 0.44 to 0.49 for $S_{1}, S_{2}$ and $S_{2} / S_{3}$ respectively. Production Index (PI) and Hydrogen Index (HI) results have a value range of 0.08 and 11.83 to 55.00 respectively. TheSoluble Organic Matter (SOM) has an average value of $0.013 \mathrm{wt} . \%(127.55 \mathrm{ppm})$, while Total organic carbon (Toc) recorded a value range of $2.40 \mathrm{wt}$. \% to $4.50 \mathrm{wt}$. \%. Thermal Alteration index (TAI) of +1 to -2 and Vitrinite reflectance (Ro \%) of $0.2 \%$ to $0.3 \%$ was recorded. Particulate organic matter of the samples was also analysed. The results suggests that the studied area is a type IVKerogen,immatured stage of thermal maturity, fair source bed,but has a high organic carbon that can generate oil
\end{abstract}

Keywords: Rock Eval pyrolysis, Hydrocarbon, Nanka Formation, Kerogen\&Anambra Basin.

\section{Introduction}

The Nigerian Eocene sediments are well dated marine deposits and unfossiliferous beds of terrestrial origin, referred by inference based on stratigraphic position, to the Eocene (Reyment, 1965). These Eocene rocks that outcropped in South-eastern Nigeria have been classified under the Ameki Group and comprises (1) Ameki Formation; whose maximum thickness ranges from 1,200 to $1,500 \mathrm{~m}$.It consists of series of highlyfossiliferous grey-green sandy clays with calcareous and white clayey sands. In different parts of the exposure,two distinct subfacies are recognized, the lower unit consists of fine to coarse sandstones with intercalations of shale and thin shelly (often coquinoid) limestone. The upper unit consists of coarse, planer cross-bedded sandstones, bands of fine grey-green sandstone and sandy clay (Nwajide, 2013). A marine depositional environment with paleobathymetric range of 10-100m was assigned to Ameki Formation by Fayose and Ola (1990) base on radiolarians belonging to the family Actinommidae, Pterocoryidae and Acanthodesmidae, which they recovered. (2) NankaFormation noted as theloose sand facies of the Ameki Group (Nwajide, 1979, 1980), the Formation outcrops over an area in excess of 1,400km exclusively east of the Niger and noted to be very susceptible to erosion. Lithologically the Formationis overwhelmingly loose, tabular to planar crossbedded, flaser-bedded, fine to medium grained sand, with a few mudrock breaks. The sand consist of subrounded to subangular grains and has an average of 5\% clay content which makes it texturally submature (Nwajide 2013). Ichnofossils such as ophiomopha, thalassinoides, chondrites and planolites are easilyidentified in the Formation. (3) Nsugbe Formation which is the third lateral equivalent within the Ameki Group is seen as a lithostatigraphic unit of formation rank distinct from the contigousNanka Formation with which it has a rather unclear boundary estimated to be $1,000 \mathrm{~km}^{2}$, the formation is strewn with ferruginous sandstone boulders, flatbedded, occasionally wave ripple-laminated, and borrowed clay, medium grained sandstone with isolated channelling and trough cross-bedding, quartz pebbly set in a matrix of coarse and poorly sorted ferruginous sandstone (Nwajide 2013). The Nanka sand underlies the study area and has been described by many authorsTattam (1944), Simpson (1955), Reyment (1965), Adegoke (1969), Nwajide (1979) Chiaghanam (2008) and Nwachukwu et al (2010). The study area is located at latitude $6^{0} 10^{\prime} 52.4^{\prime \prime} \mathrm{N}$ and longitude $6^{0} 51^{\prime} 54$. $3^{\prime \prime} \mathrm{E}$ of Ogbunike, along the Enugu-Onitsha expressway near old Onitsha tollgate in Anambra State. Itlies within the undulating lowlands of Anambra River which is of the eastern Flank. The study area is overlain by the quaternary sediments which were deposited by the fluvial actions associated with Niger and Anambra Rivers. Rocks in the area follow a NW-SE trend and good exposures could readily be found along road cuts and quarry site. Regional correlation (Short and Stauble, 1967;Avbovbo, 1978)shows that the Eocene sediments equivalent of the hydrocarbon-generating Agbada Formation of the petroliferous Niger Delta, which is mappable South- 
wards. The renewed search for hydrocarbon in the inland basins has gone beyond seismic acquisition to stratigraphic and facies studies. Most of the world's largest oil blocks are located within the siliciclastic sedimentary environment and owe their diversity and stratigraphic heterogeneity to the diverse and different depositional environments in which they were deposited (Magoon and Dow, 1994 Nwachukwu et al 2011). The presence of Dark to greenish/grey shales at different horizon in the study area have shown to be of great consequence to the presence of high abundance and diversity of fossils and might be a good source rock. The objective of the study therefore is to evaluate the shale horizon in the study area with the aim of determining the hydrocarbon potential and maturity, which will serve as model for regional basin wide prediction of Eocene Nanka Formation in respect of hydrocarbon generation. See fig 1. The goalof this research is to show how geochemical screening technology is applied to petroleum exploration aimed towards determining richness, type and thermal maturity of Nanka Formation which is a necessary step towards determining the Stratigraphic and geographic extent of a pod of active source rock in a petroleum system (Peters and Cassa, 1994).

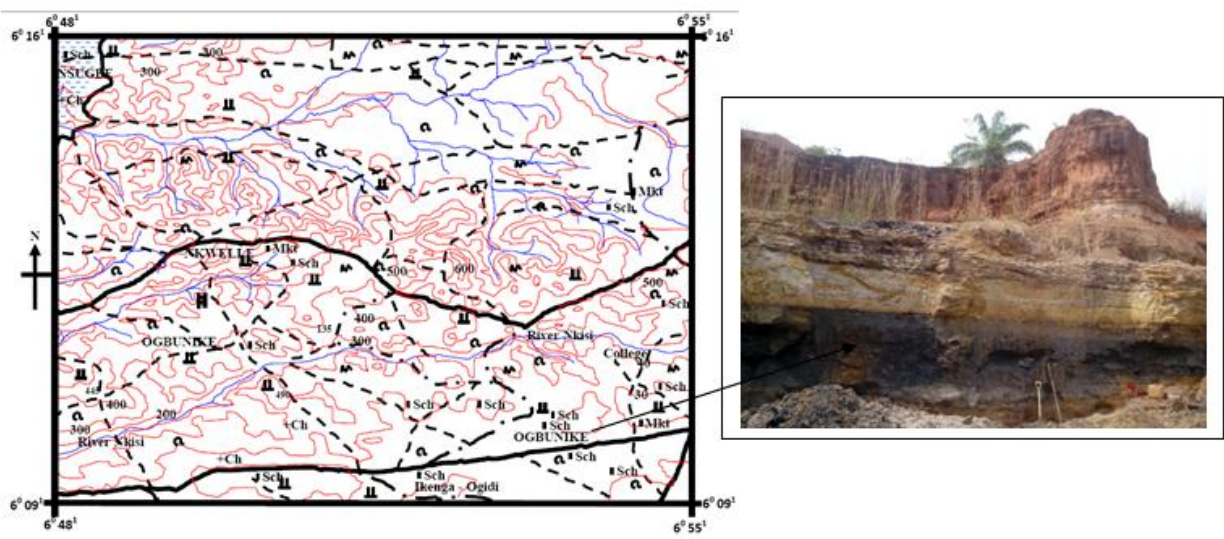

Fig 1: Map of the Study Area with the photograph inserted

\section{Geological Setting-}

Anambra Basin is located in the south-eastern part of Nigeria. The Basin is bounded to the North by Bida Basin and Northern NigeriaMassif, to the East by Benue Trough, to the West by West African Massif, and to the South by Niger Delta Complex (fig 2. map of Anambra Basin) The basinis a Cretaceous Basin having almost a roughly triangular shape with a total sediment thickness of about $9 \mathrm{~km}$, covers an area of about 40,000 sq.km. TheBasin is characterized by enormous lithological heterogeneity in both lateral and vertical extensions derived from a range of paleoenvironmentalsettings (Akaegbobi, 2005). Anambra Basin is a structural (synclinal) depression and one of the intracratonic basins in Nigeria whose origin is related to the separation of Africa from South America and the opening of South Atlantic Ocean (Ofoegbu, 1982). The basin developed due to the Santonian tectonic event which greatly affected Benue Trough, terminating sedimentation in the Abakaliki Basin but before then, sedimentation in southern Nigeria which started during Early Cretaceous was facilitated by the break-up ofthe African and South American continent resulting in the formation of Benue trough (Burke et al. 1970; Benkhelili, 1989). Sedimentation in the trough was controlled by three major tectonic phases which resulted in three successive depocentres (Murat, 1972; Oboh- Ikuenobe et al, 2005). The first phase (Albain - Santonian) was the period when Asu River Group, Eze-Aku and AwguFormations within the Abakaliki- Benue Trough were deposited. The second phase (Campanian-Eocene) was characterized by compressive movements along NE-SW axis which resulted in the folding and uplift of the trough into an anticlinorium. This forced the Anambra platform to subside and the depocenter to shift south- westwards to the newly formed Anambra Basin and the Afikpo Syncline on the other side of the anticlinorium in the southeast. The deposition of theNkporo Group, MamuFormation, Ajali Sandstone, NsukkaFormation, Imo Formation and the AmekiGroup then followed.Imo Formation and Ameki Groupwere later deposited. Third phase commenced toward the end of Eocene and this saw the structural inversion of the Abakiliki region further shifting the depocenter down dip to the south to form the Niger Delta basin. (Obi et al, 2001, Nwachukwu et al 2011). See Table 1. 


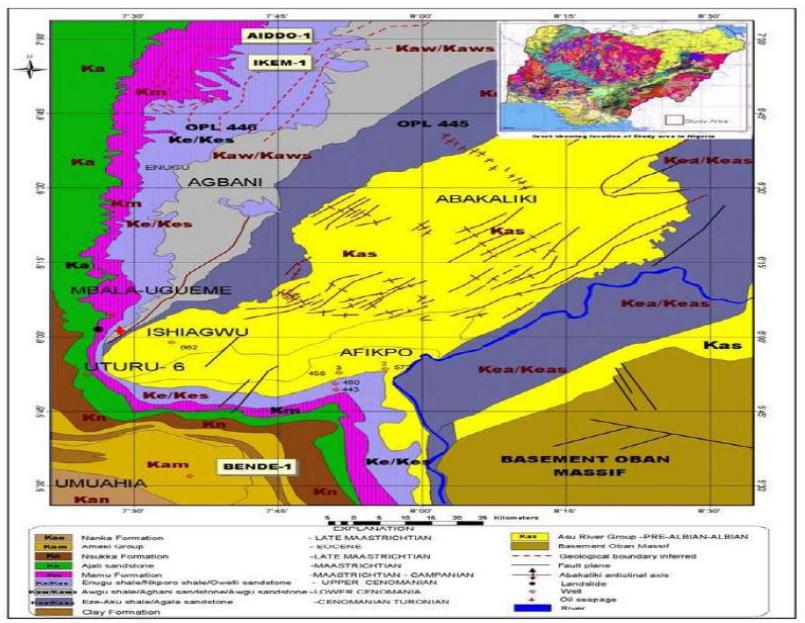

Fig. 2: Geologic Map of the Anambra Basin (adopted from Babatunde O.L. 2010)

Table1: LithostratigraphicFrameworkofAnambraBasin (afterNwajide,1990)

\begin{tabular}{|c|c|c|c|}
\hline \multicolumn{2}{|l|}{ AGE } & \multicolumn{2}{|c|}{ ABAKALIKI-ANAMBRA BA SIN $\quad$ AFIKPO BASIN } \\
\hline so my & Ollgocane & Ogwashl-A saba Formation & Ogwashl-A Baba Formation \\
\hline $54.9 \mathrm{max}$ & Eocan & AmekVNankaformation/N sugbe Sandatone & Amekl Formation \\
\hline $60 \mathrm{my}$ & Paligocan $\theta$ & $\begin{array}{l}\text { Imo Formation } \\
\text { Noukka Formation }\end{array}$ & $\begin{array}{l}\text { Imo Formation } \\
\text { Neukka Formation }\end{array}$ \\
\hline $73 \mathrm{my}$ & Masatrichtian & \begin{tabular}{|l} 
Ajalli Sandatone \\
Mamu Formation
\end{tabular} & $\begin{array}{l}\text { Ajall Sandetone } \\
\text { Imation }\end{array}$ \\
\hline 33 my & Campanian & Nkporol Owelll FormationJEnugu Shals & poro shala/Afikpo san \\
\hline $37.5 \mathrm{Nax}$ & Santonlan & Non-dөров & \\
\hline 83.5my & Conlacian & Awgu Group (Agbanl Sandatona/Awgu Shala & \\
\hline $93 \mathrm{my}$ & Turonlan & Ezagku Group) & $\begin{array}{l}\text { Ezasku Group (Incl Amagerl } \\
\text { Sandobtone) }\end{array}$ \\
\hline 100 my & nomanian- Albian & & 20u River Group \\
\hline & $\begin{array}{l}\text { Aptlan } \\
\text { Earamian } \\
\text { Hauterivian }\end{array}$ & Unamed Unite & \\
\hline & Precambrian & Bsвөment Complax & \\
\hline
\end{tabular}

\section{Materials And Methods}

The location of the out crop section were carried out using Global positioning system application. The thickness of each lithological unit was taken using a measuring tape. The rock eval pyrolysis of the shales was carried out at gatammegeochem laboratory in Port-Harcourt Nigeria. The samples were heated in an inert atmosphere to $550^{\circ} \mathrm{c}$ using a special temperature programme, which produced $S_{1}, S_{2}$ and $S_{3}$ peaks. The first peak $\left(\mathrm{S}_{1}\right)$ indicates hydrocarbon already present in the sample which are striped at thetemperature of $300^{\circ} \mathrm{c}$.Second peak $\left(S_{2}\right)$ indicates hydrocarbon that was generated due tothermal cracking of kerogen within the temperature range of $300-550^{\circ} \mathrm{c}$. Thirdpeak $\left(\mathrm{S}_{3}\right)$ indicates $\mathrm{CO}_{2}$ that are generated during the thermal cracking of kerogen. The temperature at maximum ( $\mathrm{T}$ max) was recorded at $\mathrm{S}_{2}$ peak by the instrument. Total organic carbon (Toc) and soluble organic matter (SOM) of the shale were also recorded; other important parameters such as Production Index (PI), Hydrogen Index (HI) and Oxygen Index(OI) were calculated and recorded.The rock eval pyrolysis were carried out on shale's recovered from units 25 and 28, while total organic carbon (Toc) and soluble organic matter (SOM)were carried out on shale's recoveredfrom units 21, 23, 25 and 28. The determination of total organic carbon was done using the WalkeyBlack wet oxidation method. This assessment served as a preliminary screening for further detailed rock-eval analysis.Kerogen investigation was also carried out on units $21,23,25$ and 28inother to confirm results obtained from rock eval pyrolysis.During the analysis, slides from the units were examined using the transmitted light microscopy at x10 and 40 magnifications in order to make a qualitative as well as a quantitative analysis of the Particulate Organic Matter (POM), determination of thepalynofacies and kerogen types, determination of spore/ pollen colouration and assessment of thermal alteration index (TAI), Vitrinite reflectance (Ro \%) and organic thermal maturation. Each slide was counted for its (POM) content, in which the first 200 particles were countedin terms of abundant $(>35 \%)$ frequent $(16-35 \%)$ common $(5-15 \%)$ and rare $(<5 \%)$ (Ibrahim et al, 1997). 


\section{Results And Discussion}

The levels of maturity of these samples recovered from various shale units will be dependent on depth,temperature and time of burial, and this necessitated the choose of units of 25 and 28 for rock- eval analysis.It is also a fact to note that petroleum is a generative product of organic matter disseminated in the shale and therefore the quantity of hydrocarbon directly correlated with organic matter concentration of the potential source rocks (Tissot and Welta 1984). The total organic carbon (Toc wt. \%) describes the quantity of organic carbon in a rock sample and includes bothkerogen and bitumen (Peter and Cassa 1994).

Table 2: TOC/Rock-Eval Dataset

\begin{tabular}{|l|l|l|l|l|l|l|l|l|l|l|l|l|}
\hline & & & & \multicolumn{2}{|l|}{ ROCK-EVAL } & Tmax & $\mathrm{S}_{2} / \mathrm{S}_{3}$ & PI & HI & OI \\
\hline s/no & $\begin{array}{l}\% \\
\text { SOM }\end{array}$ & $\begin{array}{l}\text { SOM } \\
(\mathrm{mg} / \mathrm{kg})\end{array}$ & $\begin{array}{l}\text { Sample } \\
\text { type }\end{array}$ & $\begin{array}{l}\text { (wt. \%). } \\
\text { Toc }\end{array}$ & $\mathrm{S}_{1}$ & $\mathrm{~S}_{2}$ & $\mathrm{~S}_{3}$ & ${ }^{\circ} \mathrm{C}$ & & & - & - \\
\hline 21 & 0.023 & 225.0 & Out crop & 2.94 & - & - & - & - & - & - & - & - \\
\hline 23 & 0.008 & 75.0 & Out crop & 4.50 & - & - & - & - & - & - & - & - \\
\hline 25 & 0.007 & 67.5 & Outcrop & 3.72 & 0.04 & 0.44 & 1.0 & 407 & 0.44 & 0.08 & 11.83 & 26.88 \\
\hline 28 & 0.014 & 142.5 & Out crop & 2.40 & 0.11 & 1.32 & 2.7 & 409 & 0.49 & 0.08 & 55.00 & 112.50 \\
\hline
\end{tabular}

The recorded total organic carbon values from the four (4) shale units as shown in table 2 above indicates that the Toc in the studies area ranges from 2.40-4.50 with an average value of 3.39.The total organic carbon suggest that the studied area has a very good Organic carbon content that can generate petroleum as shown in Peters and Cassa 1994 Geochemical parameters of petroleum potential (quantity) of an immature source rock.

The soluble organic matter (SOM) analysis carried out in the studied area was aimed at determining the source rock potential and maturity and allows for the identification of hydrocarbon rich sediments. The results of the soluble organic matter in the studied area ranges from $0.007 \mathrm{wt} \%(67.5 \mathrm{ppm})$ to $0.023 \mathrm{wt} \%(225.0 \mathrm{ppm})$, with an average value of $0.013 \mathrm{wt} \%(127.5 \mathrm{ppm})$ which indicates a fair source beds for the studied area (Deroo et al 1974).

Rock eval analysis result which was done to asses maturity for the study area show that $S_{1}$ which is the measure of hydrocarbon shows as the amount of free hydrocarbon that can be volatilized out of the rock without cracking the kerogen $(\mathrm{mg} \mathrm{Hc} / \mathrm{g}$ rock) has a value range (0.04-0.11) that indicates a poor to fair petroleum potential (PetersandCassa 1994), also $S_{2}$ which is the measure of hydrocarbon yield from cracking of kerogen ( $\mathrm{mg} \mathrm{HC} / \mathrm{g}$ rock) and heavy hydrocarbons and the existing potential of a rock to generate petroleum has a value range (0.44-1.32) that also indicates a poor petroleum potential for the studied area (Peters and Cassa 1994). $\mathrm{S}_{2} / \mathrm{S}_{3}$ that indicates the potential of the rock to generate oil has a range value (0.44- 0.49$)$ that identifies the study area as a type IVKerogen, which shows a very low atomic H/C (about 0.5-0.6) and low to high O/C ( $\leq$ $0.3)$ These kerogens are dominated byinertinitemacerals that generate little or no hydrocarbons during maturation (Peters and Cassa, 1994).

The Production or Productivity Index ( PI-S $)\left(S_{1}+S_{2}\right)$ which gradually increases with depth for fine grained rocks as thermally labile components in the kerogen $\left(\mathrm{S}_{2}\right)$, has 0.08 values for both shale units 25 and 28 . This indicates that the stage of thermal maturity for oil in the studies area is immature. (Peter andCassa 1994). The Hydrogen Index $\left(\mathrm{HI}=\left(\mathrm{S}_{2} / \mathrm{TOC}\right) \times 100, \mathrm{mg} \mathrm{HC} / \mathrm{gToc}\right)$ which is proportional to the amount of hydrogen in the kerogen has a value range (11.83 -55.00) that indicates kerogen type IV; showing that the main expelled product of peak maturity will be none (Peter and Cassa 1994).

The Tmax which is the thermal maturity and corresponds to the Rock eval pyrolysis oven temperature $\left({ }^{0} \mathrm{c}\right)$ at maximum $\mathrm{S}_{2}$ generation has a value range (407-409) that shows an immature stage of thermal maturity for oil. (Peter and Cassa 1994). From the analysis and result above, the plot of hydrogen index (Hl, MgHC/gTOC) against Tmax0c to determine the organic matter quality and maturity, confirmed that the studied area, is at immature stage of thermal maturity for oil and also of type IV kerogen. See fig. 3.

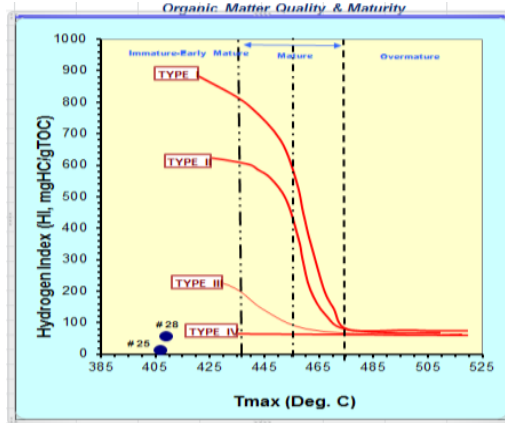

Fig 3: Organic Matter Quality and Maturity showing the Plot of Hydrogen Index (HI) against Tmax 
Also the plot of Production Index (PI $=\mathrm{S}_{1} /\left(\mathrm{S}_{1}+\mathrm{S}_{2}\right)$ against maturity (based on Tmax, ${ }^{\circ} \mathrm{c}$ ) for kerogen conversion maturity, shows that the studied area is still immature to generate oil. See Fig 4.

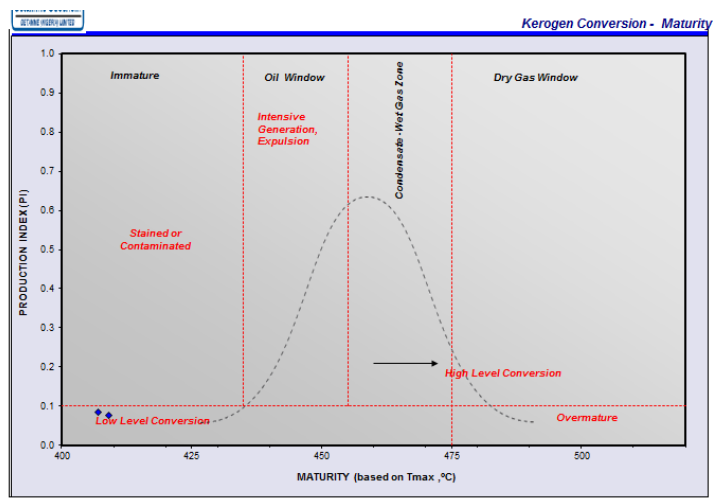

Fig. 4: Kerogen Conversion-Maturity showing the plot of Production Index (PI) against Maturity (based on $\left.\operatorname{Tmax},{ }^{\circ} \mathrm{C}\right)$.

The organic matter abundance logs plotted for Toc (wt \%) against depth shows that the studied area is rich in organic carbon and has high Toc (wt \%) value see fig. 5a while the plot of soluble organic matter (SOM $\%$ ) against depth indicate poor to fair source beds. See fig $5 \mathrm{~b}$.

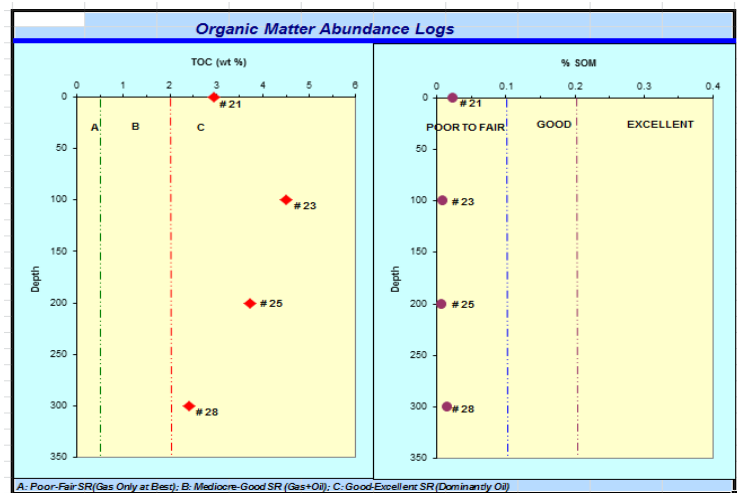

Fig. 5: a. Organic Matter Abundance Log of Total organic carbon (Toc) against Depth.

b. Organic Matter Abundance Log of Soluble Organic Matter (SOM) against Depth.

Thermal alteration index (TAI) which is a numerical scale based on thermally induced colour changes in spores and pollen was carried out in the area, a value range (+ 1 to -2$)$ that indicates a stage of thermal maturity for oil that is at its immature stage were obtained (Peters and Cassa 1994).

Vitrinity reflection (Ro \%) whose measurement are made of the percentage of incident light (usually at a wave length of $546 \mathrm{~nm}$ ) reflected from vitrinite particles (telocollinite) under oil immersion (Stach et al., 1982), was carried out and a value range $(0.2$ to $0.3 \%)$ that indicates stage of thermal maturity from oil at its immature stage was recorded (Peters and Cassa 1994, Traverse, 2007). The spore/Pollen (s/p) colour standard calibration together with other thermal maturity parameters as documented by (Pearson, 1984), ranged from pale-yellow-yellow, which corresponds to thermal alteration index (TAI) of +1 to -2 and vitriniterefletance (Ro $\%$ ) of $(0.2$ to $0.3 \%)$, as recorded in the studied area indicatesimmatured stage of thermal maturity for oil.

The frequency distributions of the total particulate organic matter (POM) presented in table 3 below and histogram \% distribution of particulate organic matter (POM) as indicated in figure 6 shows the distributions of the total particulate organic matter (POM) presents in the analyzed samples. The phytoclasts which ranged from frequent to common consists mostly of moderately to wellpreserve structured terrestrial plant fragments with pale yellow to yellowish colour (eg.tracheids, xylem tissues and cuticles). Trachieds are the most common structure phytoclast constituents usually in the form of elongate lath- shaped particules(Tyson, 1993 and Zobba et al 2007). Based on the presence of pale yellowish phytoclasts, moderately rare amorphous organic matter (AOM), dark opaque(abundant) in colour which consists of wellpreservedequant to lath- shaped fragment of varying size and form, and rare to frequent palynomorphs(Tyson 1993, Chiaghanam et al 2013),suggests a type IV kerogen for the studied area. The palynofacies association for unit 21,25 and 28 are mostly opaque debris followed by structured wood, while unit 23 has mostly opaque 
debris followed by amorphous organic matter. The micrographs of the kerogen slide showing, the various particulate organic matters (POM) of the examined samples are shown in fig 7 below.

Table 3: Summary of \% frequency distributions of the total Particulate Organic Matter (POM) present in the

\begin{tabular}{|l|l|l|l|l|}
\hline \multicolumn{5}{|c|}{ analyzed samples. } \\
\hline SAMPLE NO. & PHYTOCLAST & AOM & OPAQUES & PALYNOMORPHS \\
\hline UNIT 21 & $35 \%$ & $0 \%$ & $55 \%$ & $10 \%$ \\
\hline UNIT 23 & $13 \%$ & $37 \%$ & $48 \%$ & $2 \%$ \\
\hline UNIT 25 & $36.5 \%$ & $3 \%$ & $52.5 \%$ & $8 \%$ \\
\hline UNIT 28 & $27.5 \%$ & $3 \%$ & $65 \%$ & $4.5 \%$ \\
\hline
\end{tabular}

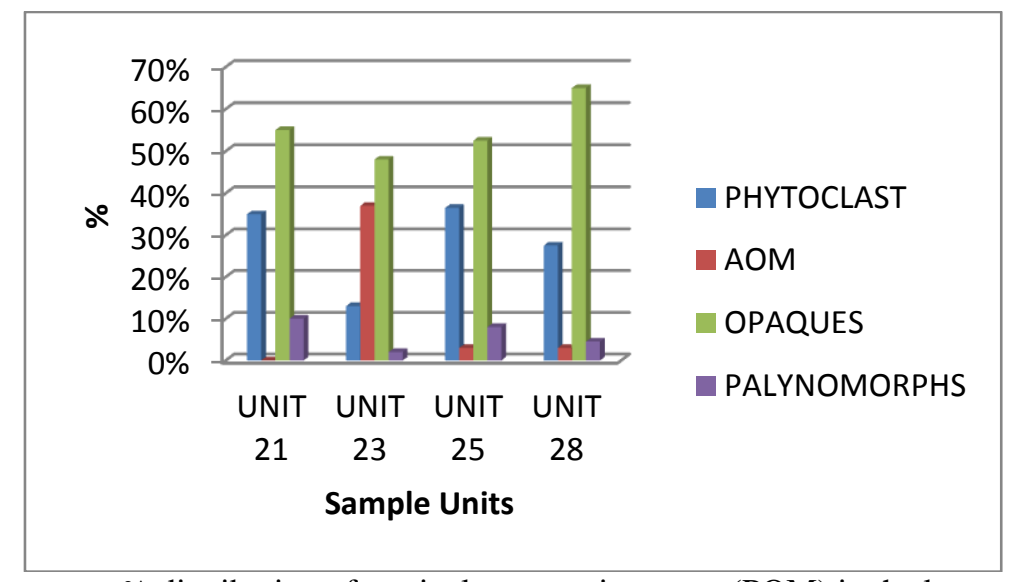

Fig. 6: Histogram \% distribution of particulate organic matter (POM) in the kerogen samples
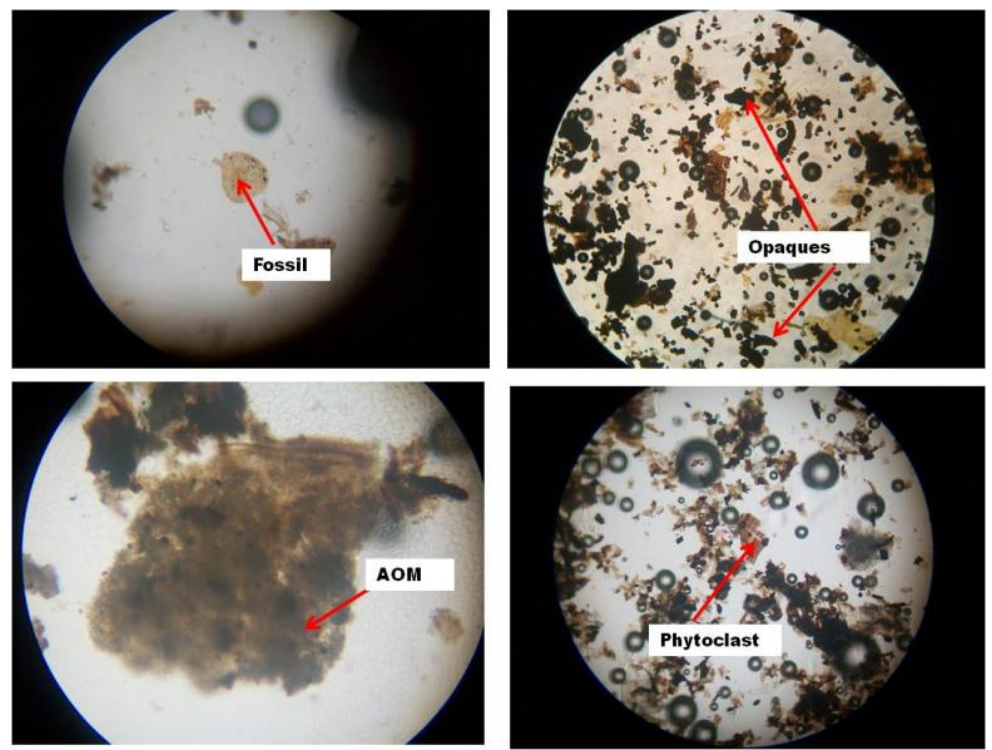

Fig. 7: Micrographs of the Kerogen slides showing the various (POM) of the examined samples.

\section{Conclusion:}

The investigated shale units of the Eocene NankaFormation at Ogbunikesoutheastern Nigeria and the results obtained from itsrock eval pyrolysis, Total organic carbon, soluble organic matters, vitrinite reflectance, thermal alteration index and particulate organic matter suggest an environment with high organic carbon content , but are immature to generate hydrocarbon.

\section{References}

[1]. Adegoke, O.S., 1969. Eocene stratigraphy of Southern Nigeria. Colloquesur 1 Eocene, III. Bureau de RechercheGeologiques et minieres, vol. 69, 20-48.

[2]. Avbovbo, A.A. 1978. Tertiary Lithostratigraphy of the Niger Delta AAPG Bulletin, Vol. 62,295-306.

[3]. Babatunde, O.L., 2010.The main oil source Formations of the AnambraBasin, South-eastern Nigeria.AAPG International Convention \&Exhibition,September 12-15, Canada 
[4]. Benkhelil, J, 1989. The Origin and Evolution of the Cretaceous Benue Trough of Nigeria: Journal of Africa Earth Sciences, Vol. 8, pp. 251-282.

[5]. Chiaghanam, O.I 2008. Lithofacies and Paleoenvironment of the Eocene sediments of Umunya in AnambraNtate, Nigeria Natural and applied science Journal, Vol. 9, No 2, 217-229.

[6]. Chiaghanam, O.L., Chiadikobi, K.C, Ikeguonu, O.N., Omoboriowo, A.A., Onyemesili., O.C and Acra E.J. 2013. Palynofacies and Kerogen analysis of offer Cretaceous (Early Campanian to Maastrichtian) Enugu Shale and Mamu Formation in Anambra Basin, South Eastern, Nigeria. International Journal of Scientific and Technology Research. Volume 2, No 8, pp. $225-229$.

[7]. Derro, G., Tissot, B., McCrossan, R.G., and Dev, F. (1974). Geochemistry of the heavy oils of Alberta. Mem. Can. Soc. Pet. Geol. 3, 148-167)

[8]. Fayose, E.A and Ola, P.S., 1990. Radiolarian occurrences in the Ameki type section Eastern Nigeria Journal of Mining and Geology. V 26, P. $75-80$.

[9]. Ibrahim, M.I.A., AbulEla, N.M., and Kholeif, S.E., 1997. Paleoecology, Palynofacies, thermal maturation and hydrocarbon sourcerock Potential of the Jurassic- Lower Cretaceous Sequence in the subsurface of the north Eastern Desert, Egypt. Quarter University Science Journal, volume 17 (1), pp. 153-172.

[10]. Magoon, L.B., and Dow, W.G, 1994. The Petroleum System from source to trap:AAPG Memoir, Vol. 60 p 665.

[11]. Nwachukwu, U.E.D., Anyiam, O.A.,Egbu, O. C. and Obi, I.S. 2011. Sedimentary controls on the reservoir properties of the PaleogeneFluvio-tidal sands of the Anambra Basin, southeastern Nigeria- implication for deeper reservoir studies American Journal of scientific and Industrial Research 2(1): pp. 37-48

[12]. Nwajide, C.S, 1979. A Lithostragraphic analysis of the Nanka sand, SoutheasternNigeria. Nigerian Journal of Mining and Geology V. 16, p 103- 109

[13]. Nwajide, C.S., 1980. Eocene tidal sediments in the Anambra Basin, Nigeria sediments. Geol, V.25, P. $189-207$.

[14]. Nwajide, S.C, 2013. Geology of Nigeria's Sedimentery Basins. CSS Bookshops. Pp. 277-518.

[15]. Obi, G.C, Okogbue, C.O and Nwajide, C.S. 2001.Evolution of the Enugu Cuesta: A tectonically driven erosion process: Global Journal of Pure and Applied Science, vol. 7, 321-330.

[16]. Oboh-Ikuenobe, F.E., Obi, G.C and Jaramillo, C.A., 2005. Lithofacies, Palynofacies and Sequence Stratigraphy of Palaeogene strata in Southeastern Nigeria: Journal of Africa Science, Vol.4,1 pp. 75-100

[17]. Pearson, D.L. 1984. Pollen/Spore Colour "standard", version 2. Phillips Petroleum Company privately distributed.Unpub. P. 5-10

[18]. Peters and Cassa. 1994.Applied Source Rock Geochemistry.Magoon, L.B, and W.G Dow, eds, 1994, The Petroleum system- from source to trip AAPG memoir 60. Pp. 93-119.

[19]. Reyment, R.A., 1965. Aspects of the Geology of Nigeria. University of Ibadan press, Nigeria, $145 \mathrm{p}$

[20]. Short, K.C., and Stauble, A.J., 1967. Outline of Geology of Niger Delta: AAPG Bulletin, Vol. 54, 750-780

[21]. Stach, E.,Mackowsky, M-Th,Teichmuller, M., Taylor, G.H., Chandra, D and Teichmuller, R. 1982. Coal petrology: GebruderBorntraeger, Berlin, p. 535.

[22]. Tissot, B.P., and Welte, D.H. 1984, Petroleum Formation and Occurrence: New York,Springer-Verlag, p. 699.

[23]. Traverse A., 2007. Paleopalynolgy, $2^{\text {nd }}$ ed.,Springer, Dordrecht, the Netherlands, p. 813.

[24]. Tyson, R.V., 1993. Palynofacies Analysis. Applied Micropalaeontology, Kluwer Academic publishers, pp 153-191.

[25]. Zobaa, M.K., Zavada, M.S and Whitelaw, M.J. 2007. Palynofacies Analysis, Source rock Evaluation and Organic Thermal Maturation of the Gray fossil site Gray,Tennessee. In: Eastern section, AAPG $36^{\mathrm{TH}}$ Annual meeting, Abstract, Lecington, Kentucky, USA, pp. 60 